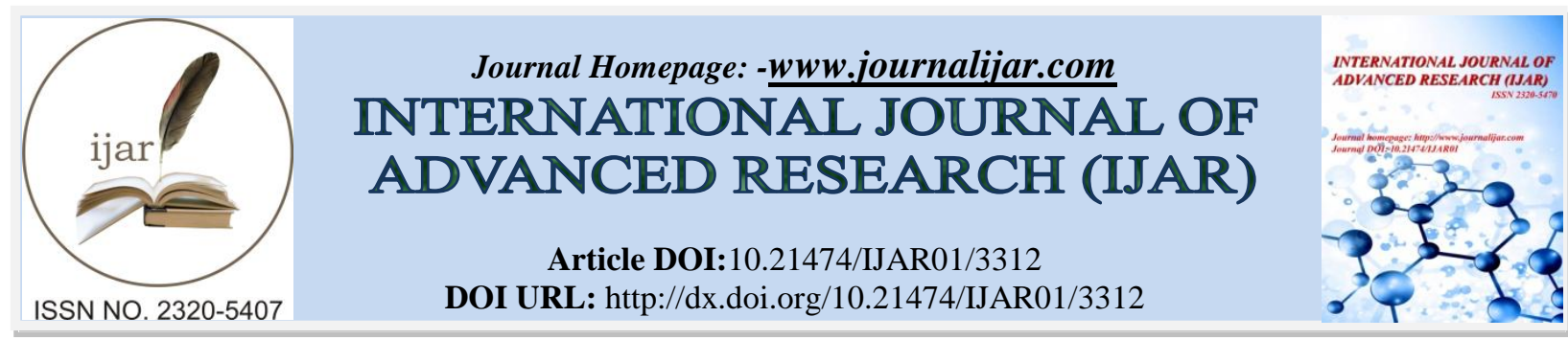

RESEARCH ARTICLE

\title{
THE IMPACT OF AGE ON SOME PHYSIOLOGICAL, HEMATOLOGICAL AND BIOCHEMICAL PARAMETERS OF NEONATAL NATIVES CALVES IN QENA, EGYPT.
}

Mohamed Saied M. M.

Mohamed Saied M. M, PH.D.,Veterinarian at GOVS (general organization of veterinary service) in Egypt.

\section{Manuscript Info}

Manuscript History

Received: 22 December2016

Final Accepted: 26 Jaunary2017

Published: Feburary2017

Key words:-

Calf, neonatal period, physiological parameters, blood parameters, biochemical parameters.

\section{Abstract}

The study was carried out on twenty calve suspected while All animals were belonged to the villages scattered in the Qena Governorate Egypt. Blood samples were taken from the external jugular vein, and then centrifuged and stored until analyses.

Blood was taken aseptically from all the animals and transported to laboratory for hematological and biochemical analysis. The hematological parameters (Hemoglobin, total erythrocyte count, total leukocyte count, packed cell volume) and biochemical parameters (Total protein, creatinine, calcium, phosphorous, iron, copper, sodium, chloride, AST, ALT) values were statistically analyzed, mean and standard deviations were calculated and set as reference values. The results showed a significant effect of days of life $(\mathrm{P}<0.05)$ only on total Rbcs, Wbcs, Hb. Total protein, Calcium, Phosphorus, Chloride, a Copper and GOT during the first week of life and a significant effect of days of life. In conclusion, modifications of studied parameters could be attributed to functional development of calves in neonatal period and contribute to the knowledge of adaptation processes in calf during the first week and the first month of life resulting useful for the diagnosis and treatment of any neonatal diseases.

The aim of this work was to follow the changes, during the early growth of calves, of a wide range of blood variables commonly used by veterinarians to aid the diagnosis of disease.

Copy Right, IJAR, 2017,. All rights reserved.

\section{Introduction:-}

Physiological, hematological and biochemical variables are most widely used medical decision making tool. Hematological and biochemical analyses of blood are very useful to get an insight in health status of animal. The neonatal period represents a critical time during which all organ functions must adapt to the extra-uterine life; it is a transition phase from the sheltered intra-uterine to the exposed extra-uterine environment (Piccione et al., 2008).

\section{Material and Methods:-}

This study was carried out in Qena governorate, Egypt, on twenty clinically healthy and full-term-born native calves (eight males: mean body weight $26.23 \pm 2.29 \mathrm{~kg}$; twelve females: mean body weight $25.21 \pm 2.1 \mathrm{~kg}$ ) which were monitored for 30 days. Calves were kept with their mothers and were fed only with maternal milk. For each calf, physiological parameters were measured and blood samples were collected at the same hour (10am).The studied parameters were assessed on all animals in the following experimental conditions: from the day after the birth, daily 
for one week and every seven days for 30 days. Rectal temperature was recorded using a digital thermometer and respiratory rate was visually recorded using a stopwatch over a $5 \mathrm{~min}$ period.

From all animals, blood samples were collected from the external jugular vein into $10 \mathrm{~mL}$ inVacutainer tubes with no addition of anticoagulants after collection all blood samples were centrifuged at 3000rpm for 10 minutes; serum were separated and stored at $-20^{\circ} \mathrm{C}$ until analyses. Serum were analyzed with commercially available kits by means of a UV spectrophotometer. Serum concentrations of the following blood parameters were measured: total protein, calcium, iron, , phosphorus, chloride, and sodium for each parameter. All results were expressed as mean \pm standard error of the means (SEM). On all data, normally distributed( $\mathrm{P}<0.05$, one way analysis of variance (ANOVA) was used to evaluate the effect of days of life during the first,second,third, and fourth week of life. If ANOVAshowed an acceptable level of significance $(\mathrm{P}<0.05)$.

\section{Results:-}

The obtained results represented in tables1,2,3,4.

Table1:- Average values ( \pm standard errors) of physiological parameters, with the statistical significances observed in twenty calves during the first month of life.

\begin{tabular}{|l|l|l|l|l|l|}
\hline & Day 1 & Day7 & Day14 & Day22 & Day30 \\
\hline Temperature & $\mathbf{3 9 . 1} \pm \mathbf{2 . 2}$ & $\mathbf{3 9 . 3} \pm 1.9$ & $\mathbf{3 9 . 2} \pm 0.5$ & $\mathbf{3 9 . 1} \pm \mathbf{3 . 1}$ & $\mathbf{3 9 . 3} \pm \mathbf{3 . 1}$ \\
\hline Breath/minute & $\mathbf{5 6 . 2} \pm \mathbf{2 . 1}$ & $\mathbf{5 7 . 1} \pm \mathbf{2 . 3}$ & $\mathbf{5 7 . 1} \pm 2.1$ & $\mathbf{5 6 . 3} \pm \mathbf{2 . 2}$ & $\mathbf{5 7 . 2} \pm \mathbf{2 . 2}$ \\
\hline Heart beat/minute & $\mathbf{1 5 6 . 1} \pm \mathbf{1 . 3}$ & $\mathbf{1 5 6 . 2} \pm \mathbf{2 . 4}$ & $\mathbf{1 5 7 . 3} \pm 2.1$ & $\mathbf{1 5 7 . 5} \pm 2.3$ & $\mathbf{1 5 7 . 3} \pm 2.3$ \\
\hline
\end{tabular}

Table2:- Average values ( \pm standard errors) of hematological parameters, with the statistical significances observed in twenty calves during the first month of life

\begin{tabular}{|l|l|l|l|l|l|}
\hline & Day 1 & Day7 & Day14 & Day22 & Day30 \\
\hline RBCs $\left.\left.10^{12} / \mathrm{L}\right)\right)$ & $7.75 \pm 1.42$ & $7.7 \pm 1.8$ & $8.2 \pm 1.2$ & $8.1 \pm 0.5$ & $8.1 \pm 0.5^{*}$ \\
& & & & & \\
\hline $\left.\mathrm{WBCs} 10^{9} / \mathrm{L}\right)$ & $9.1 \pm 2.7$ & $9.6 \pm 2.7$ & $9.3 \pm 2.7$ & $10.1 \pm 2.7$ & $10.1 \pm 2.7^{*}$ \\
\hline $\mathrm{Hb}(\mathrm{g} / \mathrm{L})$ & $104.1 \pm 13.7$ & $107.1 \pm 10.2$ & $107.1 \pm 11.3$ & $110.1 \pm 16.5$ & $110.1 \pm 15.7^{*}$ \\
\hline $\mathrm{PCV}(\mathrm{L} / \mathrm{L}))$ & $0.32 \pm 0.07$ & $0.33 \pm 0.05$ & $0.31 \pm 0.07$ & $0.34 \pm 0.02$ & $0.34 \pm 0.06$ \\
\hline
\end{tabular}

*significant at $(\mathrm{P}<0.05)$

Table 3:- Average values ( \pm standard errors) of blood parameters studied, expressed with the statistical significances observed in twenty calves during the first month of life

\begin{tabular}{|l|l|l|l|l|l|}
\hline & Day 1 & Day7 & Day14 & Day22 & Day30 \\
\hline Total protein(g/dL) & $5.75 \pm 0.88$ & $5.94 \pm 1.1$ & $5.82 \pm 1.6$ & $5.65 \pm 0.95$ & $6.92 \pm 0.9^{*}$ \\
\hline $\begin{array}{l}\text { Glucose } \\
(\mathrm{mmol} / \mathrm{L})\end{array}$ & $4.7 \pm 0.8$ & $4.8 \pm 0.6$ & $5.5 \pm 0.1$ & $4.6 \pm 0.1$ & $4.4 \pm 0.2$ \\
\hline $\begin{array}{l}\text { Urea } \\
(\mathrm{mg} / \mathrm{dL})\end{array}$ & $54.25 \pm 5.2$ & $55.25 \pm 6.7$ & $55.25 \pm 5.3$ & $54.25 \pm 4.6$ & $55.25 \pm 6.1$ \\
\hline $\begin{array}{l}\text { Creatinine } \\
(\mathrm{mg} / \mathrm{dL})\end{array}$ & $1.5 \pm 0.5$ & $1.3 \pm 0.2$ & $1.8 \pm 0.2$ & $1.22 \pm 0.1$ & $1.6 \pm 0.2$ \\
\hline $\begin{array}{l}\text { GPT/ALT } \\
(\mathrm{u} / \mathrm{l})\end{array}$ & $6.75 \pm 1.1$ & $6.65 \pm 0.3$ & $6.55 \pm 1.2$ & $6.8 \pm 0.6$ & $6.66 \pm 02$ \\
\hline $\begin{array}{l}\text { GOT/AST } \\
(\mathrm{u} / \mathrm{l})\end{array}$ & $46.5 \pm 2.4$ & $46.2 \pm 3.3$ & $48.3 \pm 2.6$ & $46.3 \pm 1.9$ & $48.2 \pm 2.3^{*}$ \\
\hline
\end{tabular}

*significant at $(\mathrm{P}<0.05)$

GPT:glutamate pyruvate transaminases.

GOT: glutamate oxalacetate transaminases. 
Table4:- Average values ( \pm standard errors) of electrolytes, expressed in their conventional units of measurement, in twenty calves during the first month of life

\begin{tabular}{|l|l|l|l|l|l|}
\hline & Day 1 & Day7 & Day14 & Day22 & Day30 \\
\hline Calcium mg/dl & $7.34 \pm 0.5$ & $7.35 \pm 4.2$ & $8.2 \pm 3.1$ & $8.1 \pm 3.2$ & $8.5 \pm 2.1^{*}$ \\
\hline $\begin{array}{l}\text { Phosphorus } \\
(\mathrm{mmol} / \mathrm{L})\end{array}$ & $2.1 \pm 0.2$ & $2.3 \pm 0.2$ & $3.1 \pm 0.1$ & $2.5 \pm 0.2$ & $2.6 \pm 0.3^{*}$ \\
\hline $\begin{array}{l}\text { Chloride } \\
(\mathrm{mmol} / \mathrm{L})\end{array}$ & $93.5 \pm 2.6$ & $93.1 \pm 2.5$ & $94.1 \pm 3.1$ & $94.1 \pm 2.1$ & $95.2 \pm 2.5^{*}$ \\
\hline $\begin{array}{l}\text { Sodium } \\
(\mathrm{mmol} / \mathrm{L})\end{array}$ & $132.5 \pm 2.2$ & $133.1 \pm 2.1$ & $134.6 \pm 3.1$ & $133.1 \pm 4.1$ & $133.6 \pm 3.4$ \\
\hline $\begin{array}{l}\text { Iron } \\
(\mu \mathrm{mol} / \mathrm{L})\end{array}$ & $25.2 \pm 1.6$ & $25.1 \pm 1.6$ & $26 \pm 2.1$ & $25.4 \pm 3.2$ & $26.1 \pm 3.1$ \\
\hline Copper mg/dl & $133.1 \pm 3.6$ & $134.2 \pm 2.3$ & $133.5 \pm 3.1$ & $134.6 \pm 3.5$ & $135.3 \pm 6.1^{*}$ \\
\hline
\end{tabular}

*significant at $(\mathrm{P}<0.05)$

Physiological parameters:-

Temperature, heart rate and breath/minute represented at table 1, the values were not increase with days.

Hematological parameters:-

Data in table 2, indicated that the values of Rbcs, Wbcs, Hb. And Pcv were increased by the day of life of calves .

Blood biochemical parameters:-

Total protein Results in table 3 indicated that, the concentrations of plasma total protein were increase from one day $(\mathbf{5 . 7 5} \pm \mathbf{0 . 8 8})$ to $(6.92 \pm 0.9 \mathrm{~g} / \mathrm{dl})$ at 30 days.

Plasma glucose Data in table 3 indicated that, the concentrations of plasma glucose were decreased with time from one day $(4.7 .8 \pm 5.2)$ to $(4.4 \pm .2 \mathrm{mg} / \mathrm{dl})$ at 30 days.

Urea values in table 3 showed that, the concentration of urea values increased with time from one day $(54.25 \pm 5.2)$ to $(\mathbf{5 5 . 2 5} \pm \mathbf{6 . 1} \mathrm{mg} / \mathrm{dl})$ at 30 days.

Creatinine Data in table 3 indicated that, the concentrations of plasma creatinine were increase in dam from zero time $(\mathbf{1 . 5} \pm \mathbf{0 5})$ to $(\mathbf{1 . 6} \pm \mathbf{0 . 2} \mathbf{m g} / \mathrm{dl})$ at 30 days.

GPT: glutamate pyruvate transaminases showing that in table 3 there are no variations of the values from one day to 30 day. $(6.75 \pm 1.1)$ to $(6.66 \pm 0.2(u / l)$.

GOT: glutamate oxalacetate transaminases data indicated that there are an increase of the values from one day $46.5 \pm 2.4$ to $48.2 \pm 2.3(u / l)$ at 30 days in table 3 .

2-blood electrolytes

Calcium level Results in table 4 indicated that there was an increase in calcium level in calves at one day (7.34 $\pm \mathbf{0 . 5})$ than at 30 day $(\mathbf{8 . 5} \pm \mathbf{2 . 1} \mathrm{mg} / \mathrm{dl})$.

Phosphorus level results in table 4 indicated that, the concentrations of plasma phosphorous were variations in the value of calves from one day $\mathbf{2 . 1} \pm \mathbf{0 . 2}$ to $\mathbf{2 . 6} \pm \mathbf{0 . 3} \mathrm{mmol} / \mathrm{L}$ ) at 30 day.

Sodium level Data in table 4 indicated that, the concentrations of plasma sodium were increased in calves from one day $(132.5 \pm 2.2)$ to133.6 $\pm 3.4(\mathrm{mmol} / \mathrm{L})$.

Chloride level Results in table4 indicated that, data indicated that there are an increase of the values from one day $(\mathbf{9 3 . 5} \pm \mathbf{2 . 6})$ to $94.1 \pm 2.1(\mathbf{m m o l} / \mathbf{L})$ at 30 days .

Iron values table 4 Results indicated that, the concentrations of plasma iron were slow increased in calves from one day (25.2 $\pm \mathbf{1 . 6})$ to $(\mathbf{2 6 . 1} \pm \mathbf{3 . 1})(\mathbf{m m o l} / \mathbf{L})$ at 30 day.

Copper values table 4 Results indicated that, the concentrations of plasma copper were increases in the value of calves from one day $(\mathbf{1 3 3 . 1} \pm \mathbf{3 . 6})$ to $(\mathbf{1 3 5 . 3} \pm \mathbf{6 . 1} \mathbf{~ m g} / \mathbf{d l})$ at 30 day.

\section{Discussion:-}

The obtained data did not show a significant effect of days of life on the studied physiological parameters (rectal temperature, heart rate, and respiratory rate) during the first month of life. Rectal temperature was between $39.1{ }^{\circ} \mathrm{C}$ and $39.3^{\circ} \mathrm{C}$ for the first days of life, with no significant differences recorded (Piccione et al., 2007b). Also in the present study for respiratory rate during the first month of life there are no significant effect of days of life on the respiratory rate. Also there is no significant effect of days of life on the heart rate. Regarding to the age influence, the results indicate the influence of the age of cattle on the red blood cells, white blood cells, hemoglobin, and packed cell volumes which are significantly more in young cattle than in adult.(Moosavianet al., 2010),(Mohriet al., 2010), ( Nezar et al.2013),(Mohriet al. 2006),(Brun-Hansen et al. 2006)and(Hege C. et al. 2006). 
Immediately after parturition the values of (PCV), haemoglobin $(\mathrm{Hb})$ and number of red blood cells are higher in newly calves(Harvey 1997), while (Mohri et al. 2007) observed a decrease of PCV and Hb from birth to the age. The obtained results showed a significant effect of days of life on total proteins, these agree with(Muri et al., 2005),EgliandBlum(1998), ( Peterson et al., 1981).Total protein data increased with the increasing the age of calves and significant at $(\mathrm{P}<0.05) \quad($ Egli and Blum(1998), (Knowles et al.2000), (Neama .A. Ashmawy2015),(CsillaTóthováet al.2016).

Plasma glucoseincrease with the increasing day of life, these agree with (Knowles et al.2000)andECLI and BLUM 1998).

The concentration of urea in blood depends from nutrition, diagnostically is important also at diseases of kidneys (Kraft \&Dürr, 1999b; Jazbec, 1990). Increased concentration of urea incalves' serum indicates increased catabolism of proteins and appears at long lastingdiarrheas (Jazbec, 1990).Hanschke and Schulz (1982), (Maria et al, 2011, Campanile et al, 1997 and, Grasso et al, 2007).the obtained results are not increase with the age of calves ,this are not agree with the results obtained byHanschke and Schulz (1982),(Hugi et al. 1997),(Knowles et al. 2000).

GOT is present in different tissues and is a sensitive indicator of soft tissue damage. In heart and skeleton musculature as in liver there is high activity of GOT,(Kurz\& Willet, 1991),Hammonand Blum (1998)glutamateoxalacetate transaminases have an increase change with day of life.,this agree with(Egli\& Blum, 1998). Mohri et al. (2007). while the (GPT )glutamate pyruvate transaminases; have no change with day of life.

Age-related changes have been detected for Calcium, and Phosphorus. Egli and Blum (1998).The obtained data showing an increase in the values of calcium (Bostedt and Schramel, 1982), WhileEgly and Blum1998)Sayed that it is decreased with the age.,

The values Sodium and chloride in the present study are increase with age, this agree with (Dubreuil and Lapierre1997), (Reece, 1984),(Maach et al., 1991).(Jozcia and Martin 2006)they reported the increase of sodiumand chloride levels with age. Other researches said that the values of $\mathrm{Cl}, \mathrm{Na}$ and $\mathrm{K}$ were within the published reference values for adult cattle. (Dubreuil and Lapierre1997).and copper with the days of life of the calves significant at $(\mathrm{P}<0.05)$ while the values, this agree with(Birgit Puschner et al.2004). For diagnostic purposes, liver copper concentrations of newborn calves are often used to determine the copper status of dams(Gooneratne and Christensen1989).

The values of phosphorus are increase with the age of calves ,this agree with(Underwood \&Suttle, 2001),(Kraft1999b) ( Rosol and Capen, 1997), (Steinhardt and Thielscher, 2000), ( Mohri et al. 2007), The iron is very important for synthesis ofhaemoglobin.The level of iron have slow increase with the increasing day of life of calves, this agree with the result achieved by(Egli and Blum 1998), (Knowles et al.2000).

Creatinine is excreted with urine. It is important for the assessment of functioning of the glomerular system in the kidneys, but it concentration increase only at serious damage (Kraft \&Dürr, 1999b).the values of creatinine obtained are not increase with the age of calves, and this are not agreewiththe results reportedby(Maach et al. (1991), (Klee, 1985), they observed increase of creatinine concentration to the age of calves.

\section{Conclusion:-}

The age of calves influence the hematological and biochemical variables what should be considered by interpretation of laboratory results.

The results of various studies on age dependent dynamics of hematological and biochemical variables in calves are different. The differences are influenced by the fact that blood samples were taken in different age periods, breeds, rearing systems, geographic regions, and were analyzed with different methods.

For proper interpretation of laboratory results it is the best to use the reference values from the laboratory which performed the analyses of blood.

The results of the present study showed that for some physiological, hematological and biochemical parameters. The results from this study provide data on 20 calves followed over time and may serve as preliminary reference 
intervals. However, because of differences between herds in relation to geographical regions, management and feeding strategies of dairy cows and calves cautions must be in mind to use appropriate reference range.

\section{References:-}

1. Birgit Puschner, Mark C. Thurmond, Young-Ku Choi (2004),Influence of age and production type on liver copper concentrations in calves,J Vet Diagn Invest 16:382-387 .

2. Bostedt, H and P.Schramel. 1982. Zurdynamik der Blutserumkonzentration von Kalzium und Magnesium sowie der SpurenelementeEisen, Kupfer und Zink in den erstenLebenswochen des Kalbes. TierkrztlicheUmschau. 37: 471- 476.

3. Brun-Hansen H.C., Kampen A.H., Lund A.(2006): Hematologic values in calves during the first 6 months of life. Vet ClinPathol, 35, 182-187.

4. Campanile,G; R. Palo and A. Dangelo. 1997.Profilometaboliconel buffalo.Suppl.n.4.Bubalis:236-249. De Garis P.J., I.J. Lean., A.R .Rabiee and M.A Stevenson. 2010. Effects of increasing days of exposure to prepartum diets concentration of certain blood metabolites in dairy cows. Australian. Vet.J.88: 137-145.

5. Carcangiu, V.; Pazzola, M.; Bua, S..,( 2002), Some hematochemical parameters pattern during first year of live in Friesian Calves. In:ATTIcongressointernazionale, 10.,2002, Tunisia. Proceedings... Tunisia:femesprum,. p.1-7.

6. CsillaTóthová, Oskar Nagy, Gabriel Kováč\&VeronikaNagyová(2016),Changes in the concentrations of serum proteins in calves during the first month of life, Journal of Applied Animal Research, 44:1, 338-34.

7. Dubreuil, P., Lapierre, H., (1997). Biochemistry reference values for Quebec dairy cows, nursing sows, growing pigs and calves. Canadian Journal of Veterinary Research 61, 235-239.

8. Dubreuil, P., Lapierre, H., 1997. Biochemistry reference values for Quebec dairy cows, nursing sows, growing pigs and calves. Canadian Journal of Veterinary Research 61,235-239.

9. Egli, C.P., Blum, J.W., 1998. Clinical, haematological, metabolic an endocrine traits during the first three months of life of suckling Simentaler calves held in a cow-calf operation. Journal of VeterinaryMedicine A 45 , 99-118.

10. Gooneratne SR, Christensen DA: (1989), A survey of maternal copper status and fetal tissue copper concentrations in Saskatchewan bovine. Can J AnimSci 69:141-150.

11. Grasso,F., G.M.Terzano ., G.Rosa., C.Tripaldi and F. Napolilan. (2007).Influence of housing conditions and calving distance on blood metabolites in water buffalo cows. Italian.J.Anim.Sci.3:273-287.

12. Hammon, H.M.; Schiessler, G.; Nussbaum, A. \& Blum, J.W. (2002). Feed intake paterns, growth performance and metabolic and endocrine traits in calves fed unlimited amounts of colostrum amd milk by automate, starting in the neonatal period.Journal of Dairy Science, Vol.85, No.12 (December 2002), pp. 3352-3362, ISSN 00220302 .

13. Hanschke, G and C.Schulz. 1982. BlutuntersuchungenbeiklinischgesundenKklbernimsubtropischenKlima (Marokko). TierkrztlicheUmschau. 37: 554-563.

14. Harvey, J.W. (1997). The erythrocyte: physiology, metabolism, and biochemical disorders. In:Clinical biochemistry of domestic animals, J.J. Kaneko, J.W. Harvey \& M.L. Bruss,(Ed.), pp. 157-203, Academic Press , ISBN 0-12-396305-2, San Diego, California.

15. Hege C. Brun-Hansen, Annette H. Kampen, Arve Lund(2006),Hematologic values in calves during the first 6 months of life,Veterinary Clinical Pathology,Vol. 35 / No. p182.

16. Hugi, D.; Gut, S.H. \& Blum, J.W. (1997). Blood metabolites and hormones -especially glucose and insulin - in veal calves: Effects of age and nutrition. Journal ofVeterinary Medicine: Series A, Vol.44, No.7 (september. 1997), pp. 407-416, ISSN 0514-7158.

17. JozicaJezek, MarijaKlopcici and Martina Klinkon(2006),influence of age on biochemical parameter in calves, Bull Vet InstPulawy 50, 211-214, 2006.

18. Klee, W.1985. Untersuchungenüber die Nierenfunktionbeigesunden und bei an akutemDurchfallerkranktenKklbern. In: KlinischeLabordiagnostik in der Tiermedizin, W. Kraft, U.M. Dürr, (Ed.), pp. 194-195, Schattauer, ISBN 978-3794519422, Stuttgart, Germany.

19. Knowles,T. G,. EdwardsJ. E, Bazeleyk. J., Brown ,S.N.,. Butterworth, A.,,Warriss, R D. (2000),Changes in the blood biochemical and hematological profile of neonatal calves with age Veterinary Record 147, 593-598

20. Kraft, W. \&Dürr, U.M. (1999b). Leber. In: KlinischeLabordiagnostik in der Tiermedizin, W.Kraft, U.M. Dürr, (Ed.), pp. 112-133, Schattauer, ISBN 978-3794519422, Stuttgart,Germany. 
21. Kurz, M.M. \& Willett, L.B. (1991). Physiology and management; carbohydrate, enzyme, and hematology dynamics in newborn calves. Journal of Dairy Science, Vol.74, No.7 (July1991), pp. 2109 - 2118, ISSN 00220302.

22. Maach, L., H.D .Gründer and A .Faio. (1991). Hkmozytologische und hkmobiochemischeUntersuchungenbeischwarzbunten, klinischgesundenAufzuchtkulbern in Marokko. Deutsche TierarztlicheWochenschrift, k.98: 77- 116.

23. Maach, L.; Gründer, H.D. \&Faio, A. (1991). Hamozytologische und hamobiochemischeUntersuchungenbeischwarzbunten, klinischgesundenAufzuchtkalberninMarokko. Deutsche TierarztlicheWochenschrift, Vol.98, No.3, (March 1991), pp. 77-116, ISSN 0341-6593.

24. Maria,S., N .Icolare., E .Marinela., B .Adrian and B. Elena.2011.Seasonal variations of some hematological and biochemical parameters of the arpathian Romanian buffaloes.Anim.Sci.Biotechnologies.44:94-98.

25. Mohri M., Sharif K I. ,Eidi .S(2007),Hematology and serum biochemistry of Holstein dairy calves:Age related changes and comparison with blood composition in adult,Research in Veterinary Science 83:30-39.

26. Mohri M., Sharifi K., Eidi S.(2007),Hematology and serum biochemistry of Holstein dairy calves:Age related changes and comparison with blood composition in adultsResearch in Veterinary Science 83 30-39.

27. Mohri, M .; Poorsina, S. \&Sedaghat, R. (2010). Effect of parenteral supply of iron on RBCparameters, performance, and health in neonatal dairy calves. Biological Trace Element Research, Vol.136,No1(July2010),

$\begin{array}{lr}\text { pp.33-39, } & \text { ISSN }\end{array}$

Moosavian H.R.; Mohri, M. \&Seifi H.A. (2010). Effect of parenteral over-supplementation of vitamin A and iron on hematology, iron biochemistry, weight gain, and health of neonatal dairy calves. Food and Chemical Toxicology, Vol.48, No.5 (May 2010),pp.1316-1320,

28. Mohri, M .; Poorsina, S. \&Sedaghat, R. (2010). Effect of parenteral supply of iron on RBCparameters, performance, and health in neonatal dairy calves. Biological Trace Element Research, Vol.136,No1(July 2010), pp.33-39, ISSN 0163-4984.

29. Muri, C., T. Schottstedt., H.M .Hammon., E .Meyer and J.W. Blum.2005. Hematological, metabolic and endocrine effects of feedning vitamin A and lactoferin in neonatal calves. J. Dairy. Sci. 88: 1062-1077.

30. Neama .A. Ashmawy(2015), Blood biochemical parameters, electrolytes and hormones in the dam and her calf after parturition of Egyptian buffalo. International Journal of Advanced Research , Volume 3, Issue 11, 1503 1513

31. NezarAdili, Mohamed Melizi and Omar Bennoune,(2013): The influence of age, sex,andaltidues on the morphometry of red blood cells in bovines. Vet.World.2013.476-478.

32. Peterson, R.G., Waldern, D.E.(1981) : Repeat abilities of serum constituents in Holstein Friesians affected by feeding, age, lactation and pregnancy. Journal of Dairy Science, 64: 822-831.

33. Piccione G, Bertolucci C, GiannettoC,GiudiceE,(2008), Clotting profiles in newborn Maltese kids during the first week of life, J Vet Diagn Invest, 20, 114-8.

34. Reece, W.O. (1984). Acid-base balance and selected hematologic, electrolytic, and blood chemical variables in calves nursing cows: one week through fifteen weeks. American .J . Vet .Res. 45: 666-669.

35. Rosol, T.J., Capen, C.C., 1997. Calcium regulating hormones and diseases of abnormal mineral (calcium, phosphorus, magnesium) metabolism. In: Kaneko, J.J., Harvey, J.W., Bruss, M.L. (Eds.), Clinical Biochemistry of Domestic Animals, fifth ed. Academic Press, San Diego, pp.619-702. 